\title{
World's 24 Biggest Agricultural Producers` Eco-Efficiency Considering Undesirable Outputs
}

\author{
Eva Richterová, Martin Richter, Jozef Palkovič \\ Department of Statistics and Operations Research, Faculty of Economics and Management, Slovak University \\ of Agriculture in Nitra, Slovakia
}

\begin{abstract}
There is still a lack of studies, which are comparing the eco-efficiency of the world's biggest agricultural producers, which affect the development of agricultural policy the most, not just EU countries. Therefore, the main goal of this article is to evaluate and compare the eco-efficiency of the world's 24 biggest agricultural producers in time and space and verifying the hypothesis that all the biggest agriculture producers are eco-efficient. Due to the improvement of technologies, we expect a positive development of agricultural eco-efficiency during the time. Eco-efficiency of the world's 24 biggest agricultural producers is computed for the years 2007 and 2017, using an output-oriented DEA model with two undesirable outputs. Data are obtained from FAOSTAT for the years 2007 and 2017. 15 countries have an eco-effective agricultural sector in both years 2007 and 2017 and could be considered as sustainable efficient countries. On average the agricultural eco-efficiency is decreasing over time. Based on the eco-efficiency values, the biggest agricultural producers are divided into three eco-efficiency agricultural groups - eco-efficiency leaders, eco-efficiency followers, and eco-efficiency laggards. According to the results, the research hypothesis that all the biggest agriculture producers are eco-efficient is not confirmed. Likewise, in general, technology improvement during time does not lead to a positive development of agricultural eco-efficiency.
\end{abstract}

\section{Keywords}

Agricultural eco-efficiency, DEA, undesirable output.

Richterová, E., Richter, M and Palkovič, J. (2021) "World's 24 Biggest Agricultural Producers' Eco-Efficiency Considering Undesirable Outputs", AGRIS on-line Papers in Economics and Informatics, Vol. 13, No. 3, pp. 89-100. ISSN 1804-1930. DOI 10.7160/aol.2021.130309.

\section{Introduction}

Still, continuous population growth exerts pressure on growing production to ensure food security. According to Sielska and Kuszewski (2016), most agricultural producers have limited possibilities for changing their production. With agricultural producers' effort to produce as much as possible with the given inputs, the efficiency inputs - outputs transformation comes to the fore. Nowadays in a highly competitive environment, efficiency is one of the most frequently applied terms to help identify the evaluated units' strengths and weaknesses (Kočišová, 2015). At the same time important sustainable and environmental goals pushing producers to avoid or reduce as much as possible the environmental consequences of their production. Therefore, the notion of eco-efficiency is becoming an integral part of all scientific, public debate, and government goals. The concept of eco-efficiency can be traced back to the 1970's as the concept of "environmental efficiency" (Freeman et al., 2014). Already in the 1970's many companies developed and begun to implement their own environmental performance goals to reach environmental efficiency. Minnesota Mining \& Manufacturing CO. (3M), for example, focused on the $3 \mathrm{P}$ (pollution prevention pays) program implementation in 1975 aiming to prevent pollution at the source (DeSimone and Popoff, 2000). This concept was firstly proposed by Schaltegger and Sturm (1990) as a "business link to sustainable development". The first definition of this notion was introduced by World Business Council for Sustainable Development (WBCSD) in 1992: "eco-efficiency is achieved by the delivery of competitively priced goods and services, that satisfy human needs and brings them life quality, while progressively reducing ecological impact and resource intensity throughout the life cycle to a level at least consistent with the earth's estimated carrying capacity" (DeSimone 
and Popoff, 2000). Later eco-efficiency was officially defined also by OECD (1998) as "the efficiency with which ecological resources are used to meet human needs".

Eco-efficiency in the simplest of terms is about achieving more with less, that means more agricultural outputs, in terms of quantity and quality, for less input of land, water, nutrients, energy, labor, or capital. This concept encompasses both the ecological and economic dimensions of sustainable agriculture (Keating et al., 2010). Eco-efficiency increases when the maintenance or growth of the production economic value corresponds to a decrease in environmental impacts (Kharel and Charmondusit, 2008). Therefore, eco-efficiency represents an important tool for assessing agriculture sustainability and also for developing strategies for policymakers, in terms of resource use and environmental impacts (UNESCAP, 2009).

Eco-efficiency is an effective index for assessing agricultural sustainability on three different levels: on macro-economic (national level), on mesoeconomic (regional level), and on micro-economic (firm-level). The movement from the firm level to the higher levels is caused by the government's interest in applying eco-efficiency principles because these are considered to results in national long-term advantages in terms of international competitiveness (Hur et al., 2004). Numerous studies with different applied methodologies are focused on the evaluation of environmental impacts that agriculture has on the environment. The most widely used approaches are the ratio approach, the material flow analysis, the sustainable value approach, and the frontier approach (Yang and Zhang, 2018). According to Zhang (2008), the ratio approach defines eco-efficiency as the relationship between the economic value of some goods and their environmental impact, but its limitation is that it can be used only if numerator and denominator can be integrated into a certain value. Mickwitz et al. (2004) and Seppälä et al. (2005) apply a ratio approach to evaluate eco-efficiency in a Finnish region of Kymenlaakso. The material flow analysis approach, especially the Life Cycle Assessment (LCA) methodology is widely used in the literature to assess eco-efficiency with the focus on a potential environmental impact that occurred throughout the whole life cycle of a product (Seppälä et al., 2005; Kicherer et al., 2007; Baum and Bienkowski, 2020). However, this approach requires large amounts of hard-to-find data with consequent approximations (Yang and Zhang, 2018).
The sustainable value approach is used to analyze eco-efficiency from a wider perspective to evaluate not just the eco-efficiency but at the same time also sustainability (Figge and Hahn, 2003; Grzelak et al., 2019). The sustainable value-added takes into account both, the efficiency and the absolute level (effectiveness) of resource use. Sustainable value-added is an extra value created when the overall level of environmental and social impacts is kept constant, and it considers simultaneously economic, environmental, and social aspects (Figge and Hahn, 2003). From all approaches mentioned above, the most common is a frontier approach, divided into parametric (Stochastic frontier analysis) and non-parametric (Data envelopment analysis). Stochastic frontier analysis (SFA) is applied to measure eco-efficiency on all possible levels - on firm-level (Orea and Wall, 2016), on a regional level (Deng and Gibson, 2019), and on a national level (Robaina-Alves et al., 2015; Shahabinejad et al., 2012). This approach permits an analysis of the potential substitutability between environmental pressures, and can easily be extended to incorporate determinants of eco-efficiency (Orea and Wall, 2016). The disadvantage of the parametric approach is that the output side can not be represented by more than one output variable, and therefore it is difficult to distinguish between desirable and undesirable variables. Data Envelopment Analysis (DEA) demonstrates great potential in the eco-efficiency measurement. DEA measures efficiency using linear programming and it is a useful methodology for aggregating different environmental impacts to construct a comprehensive eco-efficiency indicator because DEA does not require explicit weights, and can avoid the problem related to weighting in LCA (Dyckhoff and Allen, 2001). In a comparison with SFA, DEA allows us to use several output variables and take into account also the environmental consequences of production as undesirable outputs.

Several studies are applying DEA methods to analyze agricultural eco-efficiency at the firm level (Iribarren et al., 2011; Picazo-Tadeo et al., 2011; Gómez-Limón et al., 2012; Beltra'n-Esteve et al., 2014; Urdiales et al.,2016; Bonfiglio et al., 2017, Godoy-Durán et al., 2017). Different types of DEA models as CCR model (Charnes, Cooper and Rhodes), BBC model (Banker, Charnes and Cooper), FDH model (Free Disposal Hull), Super-efficiency model (SEDEA), Slack-based model (SBM), Super SBM model together with other methodological approaches are used to measure 
regional agricultural eco-efficiency in China (Liu et al., 2020; Pang et al., 2016; Yang et al., 2014) and chosen European countries - Spain (Galdeano - Gómez et al., 2017), Italy (Coluccia et al., 2020), and Poland (Masternak-Janus and RybaczewskaBlazejowska, 2016). The similar non-parametric methods - DEA techniques are applied to evaluate the eco-efficiency performance of agriculture production at the macro-level (Kočišová, 2015; Blazejowka and Gierulski, 2018; Grovermann et al., 2019). At the national and regional level researchers have developed a variety of DEA efficiency models considering undesirable outputs, representing the agricultural production outputs, which have a bad influence on the environment (Song et al., 2012; Piao et al., 2019; Fandel and Bartova, 2018).

There is still a lack of studies, which are comparing the eco-efficiency of the world's biggest agricultural producers, which affect the development of agricultural policy the most, not just EU countries. Therefore, the main goal of this article is to evaluate and compare the eco-efficiency of the world's 24 biggest agricultural producers in time and space and verifying the hypothesis that all the biggest agriculture producers are eco-efficient. Due to the improvement of technologies, we expect a positive development of agricultural eco-efficiency during the time.

\section{Material and methods}

4 input variables, namely employment in agriculture (Employment), represented by persons employed in agriculture per 1000 inhabitants, pesticides used in agriculture (Pesticide) in tones/1000 persons, fertilizers used in agriculture (Fertilizers) in tones/1000 persons, and capital consumed in agriculture (CapConsump) in dollars/person and 3 output variables, namely agricultural production (Production) in dollars/ person, $\mathrm{CH}_{4}$ emissions produced in agriculture (CH4emis) in gigagrams/100000 persons and $\mathrm{NO}_{2}$ emissions produced in agriculture (NO2emis) in gigagrams/100000 persons are selected for estimation of eco-efficiency. Agricultural production represents desirable output; $\mathrm{CH}_{4}$ emissions and $\mathrm{NO}_{2}$ emissions represent the undesirable outputs of agricultural production. The selection of variables is in line with research goals. Input and output variables are chosen to cover both the economic and environmental sides of agricultural production (Song et al., 2012; Piao et al., 2019; Fandel and Bartova, 2018). Data are obtained from FAOSTAT for the years 2007 and 2017. According to the agricultural production output value, 24 countries with the worldwide highest agricultural output are selected, namely Argentina (AR), Australia (AU), Canada (CA), Colombia (CO), Egypt (EG), France (FR), Germany (DE), Indonesia (ID), Iran (IR), Italy (IT), Japan (JP), Malaysia (MY), Mexico (MX), Pakistan (PK), Philippines (PH), Korea (KR), Russia (RU), Saudi Arabia (SA), Spain (ES), Thailand (TH), Turkey (TR), United Kingdom (GB), United States (US), Vietnam (VN).

Descriptive statistics as mean, median, standard deviation, maximum, and minimum are computed to make a multidimensional comparison of the selected countries (Yang et al., 2015; Piao et al., 2019; Coluccia et al., 2020)

Data envelopment analysis (DEA), which is a nonparametric frontier methodology, first introduced by Charnes, Cooper, and Rhodes (1978), is used to estimate the agricultural eco-efficiency of the world's biggest agricultural producers. Data envelopment analysis uses linear programming to evaluate the relative efficiencies or inefficiencies of decision-making units (DMUs) which produce multiple outputs using multiple inputs. DMUs are represented by the 24 biggest agricultural producers in the world. The DEA methodology demonstrates great potential in the eco-efficiency evaluation because no explicit weights are needed to aggregate efficiency indicators (Dyckhoff and Allen, 2001). Suppose we have $\mathrm{n}$ independent homogeneous decision-making units, denoted by $D M U_{j}(j=1,2, \ldots, n)$. For given $p$ nondiscretionary inputs $Z_{j}=\left(\begin{array}{lll}z_{l j}, & z_{2 j}, \ldots, z_{p j}\end{array}\right)^{T}$, each DMU consumes $\mathrm{m}$ discretionary inputs $X_{j}=\left(\begin{array}{llll}x_{1 j}, & x_{2 j}, \ldots, x_{m j}\end{array}\right)^{T}$ to produce $\mathrm{s}$ outputs $Y_{j}^{j}=\left(y_{l j}, y_{2 j}, \ldots, y_{s j}\right)^{T}$ (Hua, Bian, and Liang, 2007). Standard linear output-oriented CCR model with a constant return to scale could be written as following linear programming problem:

$$
\begin{gathered}
\quad \operatorname{Max} \theta_{q} \\
\sum_{j=1}^{n} y_{r j} \lambda_{j} \geq \theta Y_{r q} \quad r=1, \ldots s \\
\sum_{j=1}^{n} x_{i j} \lambda_{j} \leq X_{i q} \quad i=1, \ldots m \\
\lambda_{j} \geq 0 \quad j=1, \ldots n
\end{gathered}
$$

(Model 1)

Where $\theta_{q}$ represents the technical efficiency of the $\mathrm{DMU}_{\mathrm{q}}$ and $\lambda_{j}$ represents the weight assigned to the $D M U_{j}(j=1,2, \ldots, n)$.

During the production process under normal circumstances, undesirable outputs like 
environmental pollutants will be inevitably produced, therefore, undesirable outputs must be also taken into account in an eco-efficiency evaluation. Because we like to produce desirable outputs as much as possible and at the same time the undesirable outputs as little as possible for a given level of inputs, it is necessary to transform undesirable outputs first and then it is possible to evaluate eco-efficiency by using the traditional efficiency model based on the transformed data (Song et al., 2012).

First, each undesirable output should be multiplied by " 1 " and then a proper translation vector $w$ should be found to let all negative undesirable outputs be positive (Seiford and Zhu, 2002).

$y_{j}^{-b}=-y_{j}^{b}+w>0$

$y_{j}^{-b}=-y_{j}^{b}+\max _{j}\left(y_{j}^{b}\right)+1$

After undesirable output translation, outputoriented DEA model could be written as following linear programming problem:

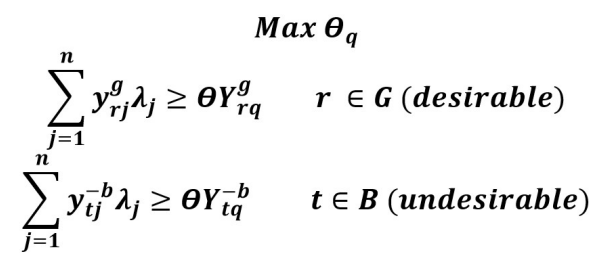

$$
\begin{gathered}
\sum_{j=1}^{n} x_{i j} \lambda_{j} \leq X_{i q} \quad i=1, \ldots m \\
\lambda_{j} \geq 0 \quad j=1, \ldots n
\end{gathered}
$$

\section{Results and discussion}

Agricultural eco-efficiency inputs and outputs variables of the chosen 24 biggest agricultural producers are analyzed in the first part of the article. Basic descriptive statistics are computed for two years -2007 and 2017 (Table 1).

The average number of persons employed in agriculture per 1000 inhabitants is decreasing from 63.76 in 2007 (Employment07 in Table 1) to 53.71 persons/1000 inhabitants in 2017 (Employment17 in Table 1). The variability of this variable is decreasing during the time $(+-59.23$ persons $/ 1000$ inhabitants in 2017, +-70.48 persons/1000 inhabitants in 2007). In both analyzed years, the median is lower than mean, which indicates that more than half of the analyzed countries have lower employment in agriculture than is the average value. The highest employment in agriculture is in both years recorded in Vietnam (227.96 persons/1000 inhabitants in 2017 and 265.45 persons/1000 inhabitants in 2007), the lowest in Argentina ( 0.16 persons $/ 1000$ inhabitants in 2017 and 3.14 persons $/ 1000$

\begin{tabular}{|c|c|c|c|c|c|c|c|c|}
\hline Variable & Units & MEAN & MEDIAN & STDEV & MAX value & MAX Country & MIN value & MIN Country \\
\hline Employment17 & $\begin{array}{l}\text { persons } / 1000 \\
\text { inhabitants }\end{array}$ & 53.71 & 27.57 & 59.23 & 227.96 & Vietnam & 0.16 & Argentina \\
\hline Employment07 & $\begin{array}{l}\text { persons } / 1000 \\
\text { inhabitants }\end{array}$ & 63.76 & 39.41 & 70.48 & 265.45 & Vietnam & 3.14 & Argentina \\
\hline Pesticide17 & $\begin{array}{c}\text { tones } / 1000 \\
\text { persons }\end{array}$ & 0.80 & 0.46 & 1.04 & 4.46 & Argentina & 0.00001 & Philippines \\
\hline Pesticide07 & $\begin{array}{l}\text { tones } / 1000 \\
\text { persons }\end{array}$ & 0.81 & 0.49 & 0.99 & 4.68 & Argentina & 0.01 & Indonesia \\
\hline Fertilizers17 & $\begin{array}{l}\text { tones/1000 } \\
\text { persons }\end{array}$ & 31.90 & 24.13 & 24.70 & 106.75 & Canada & 8.08 & Japan \\
\hline Fertilizers07 & $\begin{array}{l}\text { tones } / 1000 \\
\text { persons }\end{array}$ & 34.54 & 24.97 & 24.99 & 98.79 & Australia & 9.43 & Philippines \\
\hline CapConsump17 & dollars/person & 99.18 & 84.98 & 90.08 & 398.07 & Australia & 0.84 & Egypt \\
\hline CapConsump07 & dollars/person & 93.30 & 60.78 & 101.18 & 420.02 & Australia & 6.07 & Mexico \\
\hline Production17 & dollars/person & 635.94 & 568.18 & 289.57 & 1342.84 & Australia & 240.07 & Mexico \\
\hline Production07 & dollars/person & 626.08 & 532.83 & 334.42 & 1339.94 & Australia & 170.60 & Mexico \\
\hline CH4emis17 & $\begin{array}{c}\text { gigagrams } / 100000 \\
\text { persons }\end{array}$ & 2.47 & 1.76 & 2.99 & 14.65 & Australia & 0.34 & Saudi Arabia \\
\hline CH4emis07 & $\begin{array}{c}\text { gigagrams } / 100000 \\
\text { persons }\end{array}$ & 2.85 & 1.92 & 3.73 & 18.24 & Australia & 0.40 & Saudi Arabia \\
\hline NO2emis17 & $\begin{array}{c}\text { gigagrams } / 100000 \\
\text { persons }\end{array}$ & 0.15 & 0.10 & 0.20 & 0.99 & Australia & 0.02 & Japan \\
\hline NO2emis07 & $\begin{array}{c}\text { gigagrams } / 100000 \\
\text { persons }\end{array}$ & 0.16 & 0.10 & 0.23 & 1.15 & Australia & 0.02 & Japan \\
\hline
\end{tabular}
inhabitants in 2007).

Source: FAOSTAT, own calculations 
The average amount of pesticides used in agriculture is decreasing from 0.81 tones/1000 persons in 2007 (Pesticide07 in Table 1) to 0.80 tones/1000 persons in 2017 (Pesticide17 in Table 1). The variability of used pesticides, represented by standard deviation, is growing from 0.99 tones/1000 persons in the year 2007 to 1.04 tones/1000 persons in the year 2017. In both years the median value of this variable is markedly lower than the average, so more than $50 \%$ of analyzed countries use a lower amount of pesticides than is an average value. In both years Argentina is a country with the highest amount of pesticides used in agriculture (4.68 tones/1000 persons in 2007 and 4.46 tones/1000 persons in the year 2017). In 2007 the minimum value of pesticide used is achieving by Indonesia ( 0.01 tones/1000 persons), in 2017 by the Philippines ( 0.00001 tones/1000 persons).

The average amount of fertilizers used in agriculture is decreasing from 34.54 tones/1000 persons in 2007 (Fertilizers07 in Table 1) to 31.90 tones/1000 persons in 2017 (Fertilizers 17 in Table 1). The variability of fertilizers used is decreasing from 24.99 tones/1000 persons in 2007 to 24.70 tones/1000 persons in 2017 . Median of fertilizers used is also decreasing from 24.97 tones/1000 persons in 2007 to 24.13 tones/1000 persons in 2017, in both years is lower than mean. In the year 2007, the minimum amount of fertilizers is used in the Philippines (9.43 tones/1000 persons), the maximum in Australia (98.78 tones/1000 persons). In the year 2017 the minimum amount of fertilizers is used in Japan (8.08 tones/1000 persons), the maximum in Canada (106.75 tones/1000 persons).

The average value of the capital consumed in agriculture is growing from 93.30 dollars/person in 2007 (CapConsump07 in Table 1) to 99.18 dollars/ person in 2017 (CapConsump17 in Table 1). In both analyzed years median is lower than mean, so more than $50 \%$ of selected countries use less capital in agriculture than average. Variability of capital consumption is decreasing from 101.18 dollars/ person in 2007 to 90.08 dollars/person in 2017 . The highest capital consumption in agriculture is in both years recorded in Australia (398.07 dollars/ person in 2017 and 420.02 dollars/person in 2007). The lowest capital consumption in agriculture is recorded in 2017 in Egypt (0.84 dollars/person) and in 2007 in Mexico (6.07 dollars/person).

The average agricultural production is growing from 626.08 dollars/person in 2007 (Production07 in Table 1) to 635.94 dollars/person in 2017 (Production17 in Table 1). At the same time, the variability of agricultural production is decreasing from 334.42 dollars/person in 2007 to 289.57 dollars/person in 2017, which means, that the differences between 24 analyzed countries are decreasing. In both analyzed years the median of agricultural production is lower than its mean, which indicates that more than $50 \%$ of selected 24 countries produce less than the average value. The biggest agricultural producer in dollars/person in both years is Australia with 1339.94 dollars/ person in 2007 and 1342.84 in 2017. The lowest agricultural producer in dollars/person in both years is Mexico with 170.60 dollars/person in 2007 and 240.07 dollars/person in 2017.

The agricultural production of some selected countries grows during the analyzed time. Argentina (AR), Australia (AU), Canada (CA), Egypt (EG), Indonesia (ID), Iran (IR), Japan (JP), Malaysia (MY), Pakistan (PK), Philippines (PH), Russia (RU), Thailand (TH), United States (US) and Vietnam (VN) have higher agricultural production in 2017 than in 2007. On the other hand, agricultural production of Colombia (CO), France (FR), Germany (DE), Italy (IT), Mexico (MX), Korea (KR), Saudi Arabia (SA), Spain (ES), Turkey(TR) and United Kingdom (GB) decreases during analyzed years 2007 and 2017 (Figure 1).

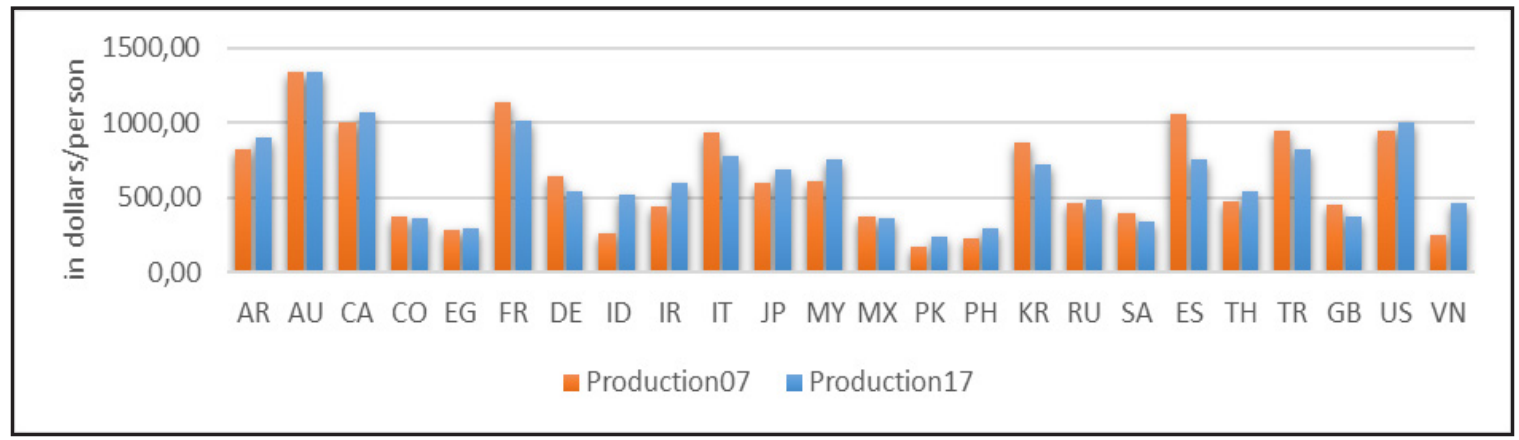

Source: FAOSTAT, own calculations

Figure 1: Agricultural production of selected 24 biggest world agricultural producers in 2007 and 2017. 
The average value of $\mathrm{CH}_{4}$ emissions produced in agriculture is decreasing during the time from 2.85 gigagrams $/ 100000$ persons in 2007 (CH4emis07 in Table 1) to 2.47 gigagrams/100000 persons in 2017 (CH4emis 17 in Table 1). Variability of $\mathrm{CH}_{4}$ emissions, expressed by standard deviation, is also decreasing during the time. In both years 2007, 2017 median of $\mathrm{CH}_{4}$ emissions is smaller than mean, which indicates that more than $50 \%$ of selected countries produce less $\mathrm{CH}_{4}$ emissions from agriculture than is average for all countries. In both years Australia, which ratified the Kyoto protocol about green gas emission reduction later than other countries, produces the highest amount of $\mathrm{CH}_{4}$ emissions (18.24 gigagrams/100000 persons in 2007 and 14.65 gigagrams/100000 persons in 2017). Saudi Arabia produces the smallest amount of $\mathrm{CH}_{4}$ emissions (0.40 gigagrams/100000 persons in 2007 and 0.34 gigagrams $/ 100000$ persons in 2017).

The agricultural $\mathrm{CH}_{4}$ emissions production of almost all selected countries decreases in the year 2017 in a comparison with the year 2007 (Figure 2). The only exceptions are Indonesia (ID), Pakistan (PK), and Turkey (TR), which produce more $\mathrm{CH}_{4}$ emissions in the year 2017 than before in the year 2007.
The average value of $\mathrm{NO}_{2}$ emissions produced in agriculture is decreasing during the time from 0.16 gigagrams/100000 persons in 2007 (NO2emis07 in Table 1) to 0.15 gigagrams/100000 persons in 2017 (NO2emis17 in Table 1). The variability of this indicator is also decreasing. In both years 2007, 2017 median of $\mathrm{CH}_{4}$ emissions is smaller than its average value, which means that more than $50 \%$ of selected countries produce less $\mathrm{NO}_{2}$ emissions from agriculture than on average. Again in both years, Australia is the biggest agricultural producer of $\mathrm{NO} 2$ emissions (1.15 gigagrams/100000 persons in 2007 and 0.99 gigagrams/100000 persons in 2017), and Japan is the lowest agricultural NO2 emission producer (0.02 gigagrams/100000 persons in 2007 and 2017).

Agricultural $\mathrm{NO}_{2}$ emissions production development in the selected countries is the same as the development of agricultural $\mathrm{CH}_{4}$ emissions production, the production is growing only in the case of Indonesia (ID), Pakistan (PK), and Turkey (TR). Other countries produce less $\mathrm{NO}_{2}$ emissions in 2017 than in 2007 (Figure 3).

In regards to environmental issues, every agricultural producer should pay attention

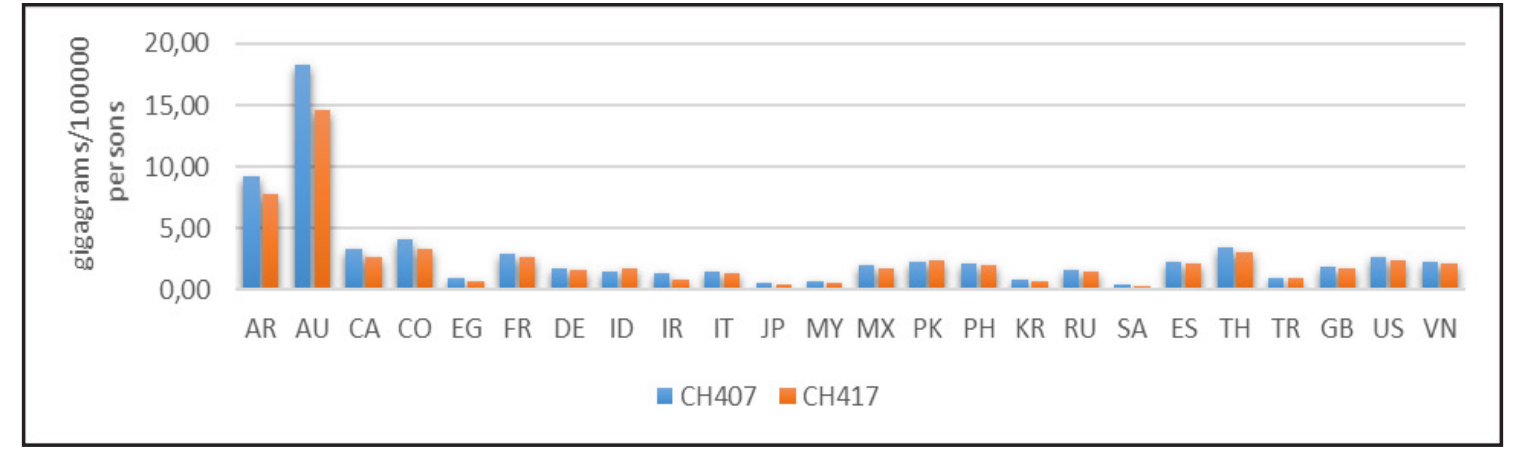

Source: FAOSTAT, own calculations

Figure 2: Agricultural $\mathrm{CH}_{4}$ emissions production of selected 24 biggest world agricultural producers in 2007 and 2017.

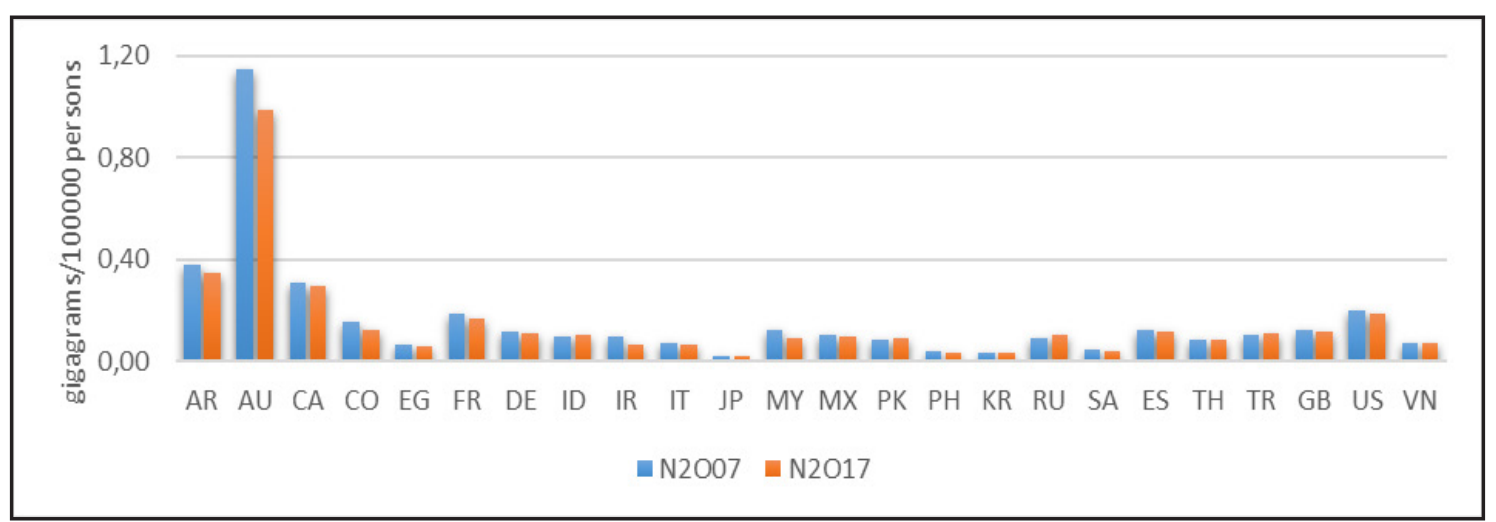

Source: FAOSTAT, own calculations

Figure 3: Agricultural $\mathrm{NO}_{2}$ emissions production of selected 24 biggest world agricultural producers in 2007 and 2017. 
to the eco-efficiency of transforming inputs into outputs. Only if the agriculture producer is eco-efficient, can produce as much agricultural output as possible with given inputs and at the same time take into account the environmental impact of its production.

Eco-efficiency of the world's 24 biggest agricultural producers is computed for the years 2007 and 2017, using an output-oriented DEA model. 2 agricultural and 2 environmental variables stand on the inputs site, namely employment in agriculture, agricultural capital consumption, pesticides use and fertilizers use. 1 agricultural and 2 environmental variables stand on the outputs side - agricultural production, $\mathrm{CH}_{4}$ emissions production, $\mathrm{N}_{2} \mathrm{O}$ emissions production. In an output -oriented model, technical efficiency can take on a value equal to 1 and higher, whereas if the country effectively transforms inputs on outputs, reaches technical efficiency (TE) equals 1. Computed TE higher than 1 means, that from given inputs could the country produce more outputs if it will be efficient.

The agricultural eco-efficiency of selected 24 biggest world agricultural producers is presented in Figure 4. 15 countries have an eco-effective agricultural sector in both years 2007 and 2017, namely Argentina (AR), Canada (CA), Egypt (EG), France (FR), Indonesia (ID), Iran (IR), Japan (JP), Korea (KR), Malaysia (MY), Mexico (MX), Philippines (PH), Saudi Arabia (SA), Spain (ES), United Kingdom (GB) and United States (US). Those 15 countries - $63 \%$ of selected countries could be considered as sustainable efficient countries. Compare to the Sielska and Kuszewski (2016) research's results still more and more countries can keep their eco-efficiency during the time, from 1996 to 2011 only 41\% of FADN regions retained their eco-efficiency but based on our results from 2007 to $201763 \%$ of analyzed countries retained their eco-efficiency. Germany (DE), Italy (IT), Russia (RU), and Vietnam (VN) are eco-effective in 2007, but not anymore in 2017. In 2017 they have TE values higher than 1 . The cause of their eco-efficiency worsening is that with their given inputs they produce less agriculture output or higher emissions as are optimal. Germany over time increases some of its inputs and despite that at the same time decreases its production value. Italy over time decreases all of its inputs and therefore at the same time decreases also production value and emissions, but not in an adequate proportion. Russia increases almost all inputs and therefore also production value, which is accompanied by a higher value of undesirable output - $\mathrm{N}_{2} \mathrm{O}$ emission production. Vietnam over time increases almost all inputs, and therefore also production value, but again also both undesirable output - emissions.

The agricultural sector in Germany is also not eco-efficient according to Blazejowka and Gierulski (2018) and Akande (2012). The different results are found out in the case of Italy, where Blazejowka and Gierulski (2018) claim that the Italian agricultural sector is eco-efficient, and in the case of France, Spain, and the United Kingdom, which they consider being an eco-inefficient. Different research conclusions could be caused by different variable selection. Pokrivčák et al. (2015) argue that Italy, France, and Spain are efficient when we are taking into account only agriculture variables, which indicates that the inefficiency of Italy is caused by environmental indicators.

In both analyzed years Australia (AU), Colombia (CO), Pakistan (PK), Thailand (TH), and Turkey (TR) reach the TE values higher than 1, so they are countries with continuously eco-ineffective agricultural sectors. From eco-ineffective countries Colombia (CO) and Pakistan (PK) get to improve their efficiency during the time, on the other hand, Australia (AU), Thailand (TH), and Turkey (TR) get even worse during the time (Figure 4). Colombia improves eco-efficiency over time because it increases its inputs and at the same time increases also production and decreases emissions. Pakistan increases over time both production and also emissions, but not to the extent of production increase, and therefore also improves its eco-efficiency. Thailand, Turkey, and Australia worsening their eco-efficiency, because they increase the production of at least one type of analyzed emissions over time.

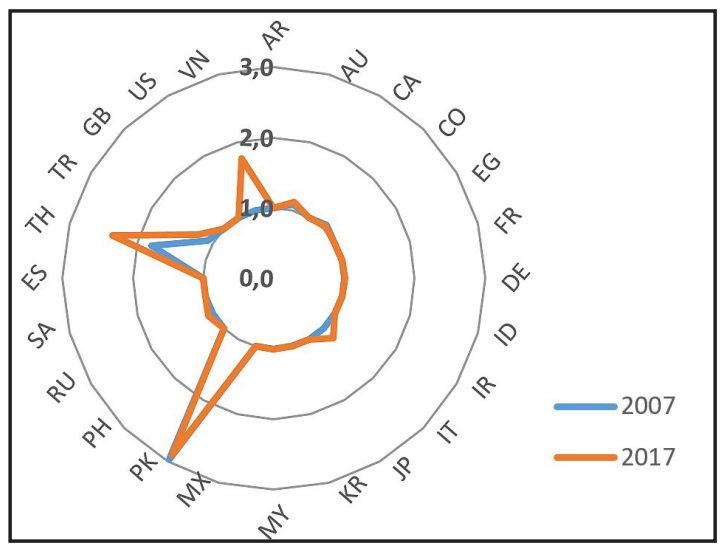

Source: FAOSTAT, own calculations

Figure 4: Agricultural eco-efficiency of selected 24 biggest world agricultural producers in 2007 and 2017. 
According to the eco-efficiency values, the biggest agricultural producers are divided into three eco-efficiency agricultural groups (Blazejowka and Gierulski, 2018):

1. eco-efficiency leaders (marked by green color in Figure 5) with TE equal to 1,

2. eco-efficiency followers (marked by purple color on Figure 5) with TE in an interval $(1,2>$,

3. eco-efficiency laggards (marked by the red color in Figure 5) with TE higher than 2

In 200719 countries (79\% of chosen countries) belong to the group eco-efficiency leaders: Argentina (AR), Canada (CA), Egypt (EG), France (FR), Indonesia (ID), Iran (IR), Japan (JP), Korea (KR), Malaysia (MY), Mexico (MX), Philippines (PH), Saudi Arabia (SA), Spain (ES), United Kingdom (GB), United States (US), Germany (DE), Italy (IT), Russia (RU), and Vietnam (VN). Australia (AU), Colombia (CO), Thailand (TH), and Turkey (TR) belong to the group eco-efficiency followers and just Pakistan (PK) belongs to the group eco-efficiency laggards with eco-efficiency higher than 2. Pakistan should improve its output variables by more than $100 \%$ (with given inputs gets higher agricultural output with fewer emissions) when wants to reach an eco-efficient agricultural sector.

On average in 2017 eco-efficiency of 24 world's biggest agricultural producers gets worst, despite the fact, that environmental protection is increasingly required. In 2017 Germany (DE), Italy (IT), Russia (RU), and Vietnam (VT), which in 2007 belongwed to the group eco-efficiency leaders, reach higher $\mathrm{TE}$ than 1 and become a part of eco-efficiency followers together with Australia (AU), Colombia (CO) and Turkey (TR). So in 2017 to the first group eco-efficiency leaders belong 15 countries $(63 \%$ of chosen countries): Argentina (AR), Canada (CA), Egypt (EG), France (FR), Indonesia (ID), Iran (IR), Japan (JP), Korea (KR), Malaysia (MY), Mexico (MX), Philippines (PH), Saudi Arabia (SA), Spain (ES), United Kingdom (GB) and United States (US). Thailand (TH), which in 2007 belongs to the group eco-efficiency followers, in 2017 reaches TE higher than 2 and together with Pakistan (PK) belongs into the group eco-efficiency laggards (Figure 5).

$63 \%$ of analyzed 24 biggest agricultural producers have an eco-efficient agricultural sector in both years, which means that with their inputs they produce as much of agricultural output as possible and at the same time as least of emissions as possible.

On average the agricultural eco-efficiency is decreasing over time. Countries as Germany, Italy, Russia, and Vietnam have a problem retaining their agricultural sector eco-efficient and with their given inputs they start to produce less agricultural output or higher emissions as are optimal.

According to the results, the research hypothesis that all the biggest agriculture producers are eco-efficient is not confirmed. Likewise, in general, technology improvement during time does not lead to a positive development of agricultural eco-efficiency.

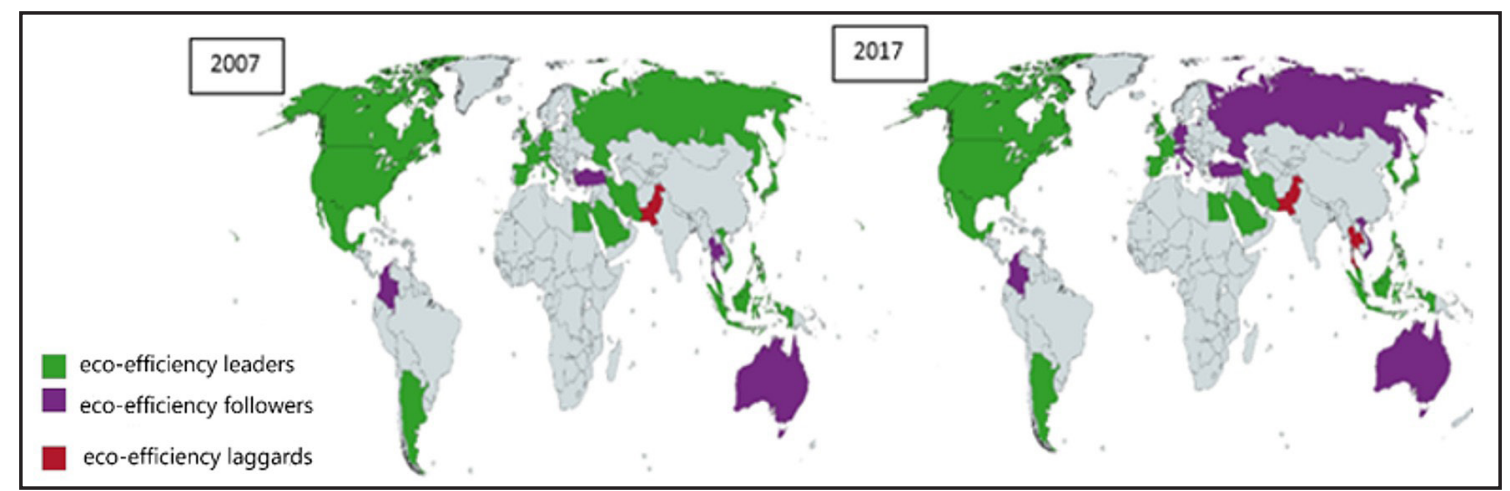

Source: FAOSTAT, own calculations

Figure 5: Groups of countries according to their eco-efficiency in 2007 and 2017. 


\section{Conclusion}

Nowadays agricultural production plays an important role in ensuring food security, due to continuous population growth. On average the 24 selected countries`agricultural production is growing over the years, but the production of 10 selected countries (Colombia, France, Germany, Italy, Mexico, Korea, Saudi Arabia, Spain, Turkey, and the United Kingdom) is decreasing during analyzed years 2007 and 2017. Only in the case that agricultural producers effectively transform their inputs on outputs, they can produce as much as possible with given inputs. During the production process in agriculture under normal circumstances, undesirable outputs like environmental pollutants will be inevitably produced. With today's pressure on the environment improvement the goal of producers is the maximization of their production output and at the same time the minimization of their impact on the environment. But it is very difficult to find a balance between those two areas. The average value of both chosen environmental output variables $\left(\mathrm{CH}_{4}\right.$ emissions, $\mathrm{NO}_{2}$ emissions $)$ for 24 selected countries is decreasing over time (the only countries with growing emissions production during analyzed years are Indonesia, Pakistan, Turkey, and Russia only with growing $\mathrm{NO}_{2}$ value). According to the computed eco-efficiency, there are 19 countries with an eco-efficient agricultural sector in 2007 (Argentina, Canada, Egypt, France, Indonesia, Iran, Japan, Korea, Malaysia, Mexico, Philippines, Saudi Arabia, Spain, United Kingdom, United States, Germany, Italy, Russia, and Vietnam). In $201764 \%$ of selected countries (15 countries) are retained their agricultural eco-efficiency compared with 2007 and could be considered as sustainable eco-efficient countries. Germany, Italy, Russia, and Vietnam are not eco-efficient, together with Colombia, Pakistan, Thailand, Turkey, and Australia. Those countries have eco-inefficient agricultural sectors, which consume too many natural resources, use too many fertilizers, and produce a considerable amount of emissions concerning the current level of agricultural production, for example, Australia is a country with the highest value of agricultural production per person, but also with the highest capital consumption, $\mathrm{CH}_{4}$ and $\mathrm{NO}_{2}$ emission production. Based on computed results, the given hypothesis "all the biggest agriculture producers are eco-efficient" is not confirmed. According to the eco-efficiency values the biggest agricultural producers are divided into eco-efficiency leaders (with $\mathrm{TE}=1$ ), eco-efficiency followers (with TE from interval $(1,2>$ ), and eco-efficiency laggards (with TE $>2$ ). In 2007, all eco-efficient countries belong to the eco-efficiency leaders. Australia, Colombia, Thailand, and Turkey are eco-efficiency followers and Pakistan is an eco-efficiency laggard. In a comparison with 2007, in 20174 eco-efficiency leaders become eco-efficiency followers (Germany, Italy, Russia, Vietnam) and Thailand becomes an eco-efficiency laggard. When we compare the agricultural eco-efficiency changes during the years 2007 and 2017, we can conclude that on average the agricultural eco-efficiency is decreasing over time, and in general technology improvement during the time does not lead to a positive development of agricultural eco-efficiency. Finally, the results of the applied output-oriented DEA method show if the agriculture sector of chosen countries are eco-effective, or not, but it is necessary to investigate deeply the reasons for countries' inefficiency. Future research, based on the findings obtained in this study, can unfold by using the combination of several methodological approaches, as the combination of The SlacksBased Measure (SBM) of efficiency, Malmquist productivity index, and Tobit model.

\section{Acknowledgments}

This paper is connected to project no. $2 / 2021 / \mathrm{GA}$ FEM named "EU Eco-efficient agriculture - current challenges".

\section{Corresponding authors}

Ing. Eva Richterová, Ph.D.

Department of Statistics and Operations Research, Faculty of Economics and Management Slovak University of Agriculture in Nitra, Trieda A. Hlinku 2, 94976 Nitra, Slovak Republic Phone: +421376414162,E-mail: eva.richterova@uniag.sk 


\section{References}

[1] Akande, O. P. (2012) "An evaluation of technical efficiency and agricultural productivity growth in EU regions", Wageningen University, Aug. 2012. [Online]. Available: https://edepot.wur. nl/222208 [Accessed: 27 May 2020].

[2] Baum, R. and Bienkowski, J. (2020) "Eco-Efficiency in Measuring the Sustainable Production of Agriculture Crops", Sustainability, Vol. 12, No. 4, pp. 14-18. ISSN 2071-1050. DOI 10.3390/su12041418.

[3] Beltra'n-Esteve, M., Go'mez-Limo'n, J. A., Picazo-Tadeo, J. A. and Reig-Martı'nez, E. (2014) "A metafrontier directional distance function approach to assessing eco-efficiency", Journal of Productivity Analysis, Vol. 41, No. 1, pp. 69-83. ISSN 15730441. DOI 10.1007/s11123-012-0334-7.

[4] Blazejowska, M. R. and Gierulski, W. (2019) "Eco-Efficiency Evaluation of Agricultural production in the EU-28", Sustainability, Vol. 10, No. 12, pp. 45-44. ISSN 2071-1050. DOI 10.3390/su10124544.

[5] Bonfiglio, A., Arzeni, A. and Bodini, A. (2017) "Assessing eco-efficiency of arable farms in rural areas", Agricultural Systems, Vol. 151, pp. 114-125. ISSN 1873-2267. DOI 10.1016/j.agsy.2016.11.008.

[6] Coluccia, B., Valente, D., Fusco, G., De Leo, F. and Porrini, D. (2020) "Assessing agricultural eco-efficiency in Italian Regions", Ecological Indicators, Vol. 116, Sep. 2020. ISSN 1872-7034. DOI 10.1016/j.ecolind.2020.106483.

[7] Charnes, A., Cooper, W. W. and Rhodes, E. (1978) "Measuring the efficiency of decision making units", European Journal of Operational Research, Vol. 2, No. 6, pp. 429-444. ISSN 1872-6860. DOI 10.1016/0377-2217(78)90138-8.

[8] Deng, X. and Gibson, J. (2019) "Improving eco-efficiency for the sustainable agricultural production: A case study in Shandong, China", Technological Forecasting \& Social Change, Vol. 144, pp. 394-400. ISSN 1873-5509. DOI 10.1016/j.techfore.2018.01.027.

[9] DeSimone, L. D. and Popoff, F. (2000) "Eco-Efficiency: The business Link to Sustainable Development", The MIT Press, Massachusetts, p. 308, ISBN 978-0262541091.

[10] Dyckhoff, H. and Allen, K. (2001) "Measuring ecological efficiency with data envelopment analysis", European Journal of Operational Research, Vol. 132, No. 2, pp. 312-325. ISSN 1872-6860. DOI 10.1016/S0377-2217(00)00154-5.

[11] Fandel, P. and Bartova, L. (2018) "Eco-efficiency using directional distance functions with undesirable outputs, In: Quantitative methods in economics, 412 p. Bratislava: Letra Edu, pp. 87-95. ISBN 978-80-89962-07-5 (book), ISBN 978-80-89962-08-2 (Collection of papers).

[12] Freeman, A. M., Herriges, J. A. and Kling, C. L. (2014) "The measurement of Environmental and Resource values ", RFF Press, London, p. 479, ISBN 978-1-315-78091-7.

[13] Figge, F. and Hahn, T. (2003) "Sustainable Value Added - measuring corporate contributions to sustainability beyond eco-efficiency", Ecological Economics, Vol. 48, No. 2, pp. 173-187. ISSN 1873-6106. DOI 10.1016/j.ecolecon.2003.08.005.

[14] Godoy-Durán, A., Galdeano-Gómez, E. and Pérez-Mesa, J. C. (2017) "Assesing eco-efficiency and the determinants of horticultural family - farming in southeast Spain", Journal of Environmental Management, Vol. 204, pp. 594-604. ISSN 1095-8630. DOI 10.1016/j.jenvman.2017.09.037.

[15] Gómez-Limón, J. A., Picazo-Tadeo, J. A. and Reig-Martínez, E. (2012) "Eco-efficiency assessment of olive farms in Andalusia", Land Use Policy, Vol. 29, No. 2, pp. 395-406. ISSN 1873-5754. DOI 0.1016/j.landusepol.2011.08.004.

[16] Grovermann, Ch., Wossen, T., Muller, A. and Nichterlein, K. (2019) "Eco-efficiency and agricultural innovation systems in developing countries: Evidence from macro-level analysis", PLOS ONE, Vol. 14, No. 4. ISSN 1932-6203. DOI 10.1371/journal.pone.0214115. 
[17] Grzelak, A., Guth, M., Matuszczak, A., Czyzewski, B. and Brelik, A. (2019) "Approaching the environmental sustainable value in agriculture: How factor endowments foster the eco-efficiency", Journal of Cleaner Production, Vol. 241. ISSN 1879-1786. DOI 10.1016/j.jclepro.2019.118304.

[18] Hua, Z., Bian, Y. and Liang, L. (2007) "Eco-efficiency analysis of paper mills along the Huai River: An extended DEA approach", Omega, Vol. 35, No. 5, pp. 578-587. ISSN 2502-2318. DOI 10.1016/j.omega.2004.10.004.

[19] Iribarren, D., Hospido, A., Moreira, M. T. and Feijoo, G. (2011) "Benchmarking environmental and operational parameters through eco-efficiency criteria for dairy farms", Science of the Total Environment, Vol. 409, No. 10, pp. 1786-1798. ISSN 1879-1026. DOI 10.1016/j.scitotenv.2011.02.013.

[20] Keating, B. A., Carberry, P. S., Bindraham, P. S., Asseng, S., Meinke, H. and Dixon, J. (2010) "Eco-efficient Agriculture: Concepts, Challenges, and Opportunities", Crop Science, Vol. 50, No. S1, pp.109-119. ISSN 1435-0653. DOI 10.2135/cropsci2009.10.0594.

[21] Kharel, G. P. and Charmondusit, K. (2008) "Eco-efficiency evaluation of iron rod industry in Nepal", Journal of Cleaner Production, Vol. 16, No. 13, pp. 1379-1387. ISSN 1879-1786. DOI 10.1016/j.jclepro.2007.07.004.

[22] Kicherer, A., Schaltegger, S., Tschochohei, H. and Pozo, B. F. (2020) "Eco-Efficiency. Combining Life Cycle Assessment and Life Cycle Costs Via Normalization", The International Journal of Life Cycle Assessment, Vol. 12. No. 7, pp. 537-543. ISSN 1614-7502. DOI 10.1065/lca2007.01.305.

[23] Kočišová, K. (2015) "Application of the DEA on the measurement of efficiency in the EU countries", Agricultural Economics (AGRICECON), Vol. 61, No. 2, pp. 51-62. ISSN 1805-9295. DOI 10.17221/107/2014-AGRICECON.

[24] Masternak-Janus, A. and Rybaczewska-Blazejowska, M. (2016) "Comprehensive Regional Eco-Efficiency Analysis Based on Data Envelopment Analysis", Journal of Industrial Ecology, Vol. 21, No. 1, pp. 180-190. ISSN 1530-9290. DOI 10.1111/jiec.12393.

[25] Mickwitz, P., Melanen, M., Rosenstrom, U. and Seppälä, J. (2005) "Regional eco-efficiency indicators - a participatory approach", Journal of Cleaner Production, Vol. 14, No. 18, pp. 1603-1611. ISSN 1879-1786. DOI 10.1016/j.jclepro.2005.05.025.

[26] Orea, L. and Wall, A. (2017) "A Parametric Approach to Estimating Eco-Efficiency", Journal of Agriculture Economics, Vol. 68, No. 3, pp. 901-907. ISSN 1477-9552. DOI 10.1111/1477-9552.12209.

[27] Organisation for Economic Co-operation and Development (OECD) (1998) "Eco-efficiency". OECD [Online]. Available: http://www.oecd-ilibrary.org/docserver/9789264040304-en.pdf? e x p i r e s = $1610456534 \&$ i d = i d \& a c c n a m e $=$ g u e s t \& c h e c k s u m =4EAAB98051BF6FC5C1187040ACD321F7 [Accessed: 27 May 2020].

[28] Robaina-Alves, M., Moutinho, V. and Macedo, P. (2015) "A new frontier approach to model the eco-efficiency in European countries", Journal of Cleaner Production, Vol. 103, No. 15, pp. 562-573. ISSN 1879-1786. DOI 10.1016/j.jclepro.2015.01.038.

[29] United Nation Economic and Social Commission for Asia and Pacific (UNESCAP) (2009) "Eco-efficiency indicators: Measuring Resource-use Efficiency and the Impact of Economic Activities on the Environment. Greening of Economic Growth series". UNESCAP, 2009. [Online]. Available: https://sustainabledevelopment.un.org/content/documents/785eco.pdf [Accessed: 27 May 2020].

[30] Urdiales, M. P., Lansink, A. O. and Wall, A. (2016) "Eco-efficiency Among Dairy Farmers: The Importanceof Socio-economic Characteristics and Farmer Attitudes", Environmental and Resource Economics, Vol. 64, No. 4, pp. 559-574. ISSN 1573-1502. DOI 10.1007/s10640-015-9885-1.

[31] Hur, T., Kim, I. and Yamatoto, R. (2004) "Measurement of green productivity and its improvements", Journal of Cleaner Production, Vol. 12, No. 7, pp. 673-683. ISSN 1879-1786. DOI 10.1016/j.jclepro.2003.08.004. 
[32] Pang, J., Xingpeng, Ch., Zhang, Z. and Li, H. (2016) "Measuring Eco-Efficiency of Agriculture in China", Sustainability, Vol. 8, No. 4, 398 p. ISSN 2071-1050. DOI 10.3390/su8040398.

[33] Picazo-Tadeo, A. J., Gómez-Limón, A. J. and Reig-Martínez E. (2011) "Assessing farming eco-efficiency: A Data Envelopment Analysis approach", Journal of Environmental Management, Vol. 92, No. 4, pp. 1154-1164. ISSN 1095-8630. DOI 10.1016/j.jenvman.2010.11.025.

[34] Piao, S. R., Li, J. and Ting, Ch.-J. (2019) "Assessing regional environmental efficiency in China with distinguishing weak and strong disposability of undesirable outputs", Journal of Cleaner Production, Vol. 227, No. 1, pp. 748-759. ISSN 1879-1786. DOI 10.1016/j.jclepro.2019.04.207.

[35] Pokrivčák, J., Záhorský, T. and Svetlanská, T. (2015) "Evaluation of technical efficiency and productivity of agriculture in EU Member States", Proceedings ICABR 2015, Brno, pp. 793-806, ISBN 978-80-7509-379-0.

[36] Schaltegger, S. and Sturm, A. (1990) "Ökologische Rationalität: Ansatzpunkte zur Ausgestaltung von ökologieorientierten Managementinstrumenten", Die Unternehmung, Vol. 44, No. 4, pp. 273-290. ISSN 0042-059X.

[37] Seiford, M. L. and Zhu, J. (2002) "Modeling undesirable factors in efficiency evaluation", European Journal of Operational Research, Vol. 142, No. 1, pp. 16-20. ISSN 1872-6860. DOI 10.1016/S0377-2217(01)00293-4.

[38] Seppälä, J., Melanen, M., Mäenpää, I., Koskela, S., Tenhunen, J. and Hiltunen, M. R. (2005) "How Can the Eco-efficiency of a Region be Measured and Monitored?", Journal of Industrial Ecology, Vol. 9, No. 4, pp. 117-130. ISSN 1530-9290. DOI 10.1162/108819805775247972.

[39] Shahabinejad, V., Zamanian, Gh. R. and Yaghoubi, M. (2012) "Application of DEA and SFA on the Measurement of Agricultural Technical Efficiency in MENA Countries", International Journal of Applied Operational Research, Vol. 3, No. 2, pp. 43-51. ISSN 2251-9432.

[40] Sielska, A. and Kuszewski, T. (2016) "The Efficiency of Agricultural Production in FADN Regions in 1996-2011", Journal of Central European Agriculture, Vol. 17, No. 3, pp. 835-855. ISSN 1332-9049. DOI 10.5513/JCEA01/17.3.1781.

[41] Song, M., Qingxian, A., Zhang, W., Wang, Z. and Wu, J. (2012) "Environmental efficiency evaluation based on data envelopment analysis: A review", Renewable and Sustainable Energy Reviews, Vol.16, No. 7, pp. 4465-4469. ISSN 1364-0321. DOI 10.1016/j.rser.2012.04.052. 